\title{
Antifungal Sesquiterpenoids, Rhodocoranes, from Submerged Cultures of the Wrinkled Peach
}

\section{Mushroom, Rhodotus palmatus}

Birthe Sandargo, ${ }^{\dagger, \S}$ Maira Michehl, ${ }^{\dagger, \S}$ Marc Stadler, ${ }^{\dagger, \S}$ Frank Surup ${ }^{*,+, \S}$

${ }^{\dagger}$ Department of Microbial Drugs, Helmholtz Centre for Infection Research GmbH, Inhoffenstraße 7, 38124 Braunschweig, Germany

${ }^{\S}$ German Centre for Infection Research (DZIF), partner site Hannover-Braunschweig, 38124

Braunschweig, Germany. 
Seven previously unknown sesquiterpenoids and norsesquiterpenoids, rhodocoranes F-L (1-7), were isolated from the fermentation broth of the basidiomycete Rhodotus palmatus. Their structures were elucidated utilizing 1D and 2D NMR techniques as well as HRESIMS; they are unusual noracorane, spiro[4.4]nonene, and acorane-type sesquiterpenoids. They include the first naturally-occurring cyclopentylidenefuranones (3 - 5) and the new tricyclic scaffold of 7. Metabolites 1 - $\mathbf{7}$ exhibited a general mild antimycotic activity, while $\mathbf{1}-\mathbf{3}$ also displayed cytotoxic effects.

\section{GRAPHICAL ABSTRACT}
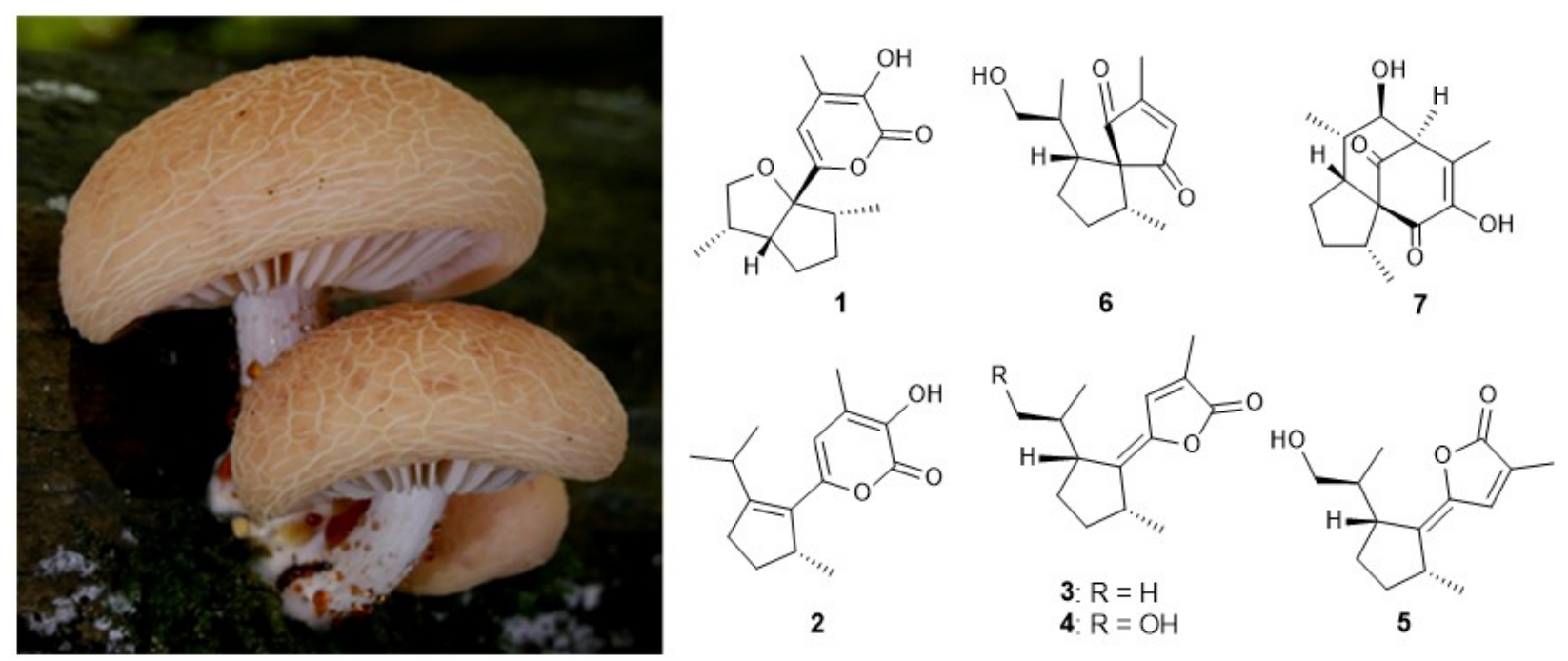
In recent years Basidiomycota have become an important focus in the search for novel bioactive secondary metabolites, ${ }^{1}$ with the basidiomycete-derived pleuromutilins as the most recent group of antibiotics to enter the market. ${ }^{2}$ While the center of attention has been on largely understudied, unknown tropical mushrooms, ${ }^{3}$ there are also several examples of bioactive metabolites derived from rarer species of the temperate regions. ${ }^{4}$ One such example is the wrinkled peach mushroom, Rhodotus palmatus (Bull.) Maire., ${ }^{5,6}$ This unmistakable mushroom, with its striking pink caps, deep engravings, and blood-like drops covering younger fruiting bodies, is a pioneer fungus on freshly rotting hardwoods, with a preference for elm trees. ${ }^{7}$ The finding of this endangered species in Germany has lead us to isolate in an initial study its first reported secondary metabolite, the meroterpenoid rhodatin, with a unique pentacyclic scaffold and both spiro and spiroketal centers, and five acorane-type sesquiterpenoids. ${ }^{8}$ Inspired by this innovative chemistry, we continued the investigation of the mushroom's secondary metabolites, leading to the isolation and structure elucidation of seven unprecedented sesquiterpenoids and norsesquiterpenoids, rhodocoranes F-L (1-7) with cytotoxic and antimicrobial activity.

Rhodocorane F (1), was isolated by preparative RP-HPLC as a clear oil and found to possess a molecular formula of $\mathrm{C}_{15} \mathrm{H}_{20} \mathrm{O}_{4}$, based on HRESIMS analysis. Its ${ }^{1} \mathrm{H}$ and ${ }^{13} \mathrm{C}$ NMR data (Table 1) display a high similarity to the previously published rhodocorane A with the key difference of the replacement of the hydroxy function at C-2 with an additional methylene $\left(\delta_{\mathrm{C}} 34.9\right){ }^{8}$ Analyzing its ${ }^{1} \mathrm{H},{ }^{1} \mathrm{H}$ COSY and ${ }^{1} \mathrm{H},{ }^{13} \mathrm{C}$ HMBC data 1 was elucidated as 2-dehydroxyrhodocorane A, and named rhodocorane F. ${ }^{1} \mathrm{H},{ }^{1} \mathrm{H}$ ROESY correlations of $\mathbf{1}$ (particularly the one between $1-\mathrm{H}$ and $4-\mathrm{H}$ ) were similar to the ones observed for rhodocorane A, whose absolute stereochemistry had been assigned by Mosher's method. Consequently, the absolute configuration of rhodocorane $\mathrm{F}(\mathbf{1})$ is suggested based on an assumed analogy as $1 R, 4 R, 5 R, 11 S$. The absolute 
configuration of the rhodocorane family was confirmed by comparison of the optical rotations of those of its members with closely related compounds. The positive optical rotations of rhodocoranes $\mathrm{B}-\mathrm{E}$ (see Figure $\mathrm{S} 1$ ) indicated a $1 R, 4 R$ absolute configuration, since structurally related ent-acorenone and ent-trichoacorenol with confirmed $1 R, 4 R$ absolute configuration possess positive optical rotations, in contrast to acorenone, acorenone B and trichoacorenol with confirmed $1 S, 4 S$ absolute stereochemistry having negative ones. ${ }^{9,10}$ The configuration of C-5 has apparently only minor influence, since both acorene and its spiro-epimer acorenone B have both negative values.

Rhodocorane $\mathrm{G}(2)$, with a molecular formula of $\mathrm{C}_{15} \mathrm{H}_{20} \mathrm{O}_{3}$, possessed one oxygen atom less than $\mathbf{1} .{ }^{1} \mathrm{H}$ and ${ }^{13} \mathrm{C}$ NMR data of $\mathbf{2}$ were very similar to those of $\mathbf{1}$. However, oxymethylene $\mathrm{CH}_{2}-$ 12, methine $\mathrm{CH}-4$ and $\mathrm{C}-5$ of $\mathbf{1}$ are replaced by a methyl group and two olefinic carbons, respectively. Analysis of its 2D NMR data retrieved the 9-hydroxy-8-methyl-pyranone moiety of 1, with a slight upfield shift $\left(\Delta \delta\right.$ 7.1) of C-6 $\left(\delta_{\mathrm{C}} 155.3\right)$. The latter can be explained by an additional double bond between C-4 ( $\left.\delta_{\mathrm{C}} 150.9\right)$ and C-5 ( $\left.\delta_{\mathrm{C}} 130.2\right)$, verified through HMBC correlations of $1-\mathrm{H}, 2-\mathrm{H}, 12-\mathrm{H}_{3}, 13-\mathrm{H}_{3}$ to $\mathrm{C}-4$, as well as $2-\mathrm{H}, 3-\mathrm{H}, 11-\mathrm{H}, 14-\mathrm{H}_{3}$ to $\mathrm{C}-5$. In combination with the ${ }^{1} \mathrm{H},{ }^{1} \mathrm{H}$ TOCSY spin system of $14-\mathrm{H}_{3} / 1-\mathrm{H} / 2-\mathrm{H} / 3-\mathrm{H}$ and $12-\mathrm{H}_{3} / 11-\mathrm{H} / 13-$ $\mathrm{H}_{3}$, this established a 1-methyl-4-isopropyl-cyclopent-4-ene moiety. The connection of the two moieties between $\mathrm{C}-5$ and C-6 was confirmed through a long-range ${ }^{1} \mathrm{H},{ }^{13} \mathrm{C}$ HSQMBC correlation of $\mathrm{H}-7$ to $\mathrm{C}-5$, which was only very weak in the $\mathrm{HMBC}$ spectrum.

Rhodocorane H (3) shows a certain analogy to 2, for which HRESIMS data indicates a molecular formula of $\mathrm{C}_{14} \mathrm{H}_{20} \mathrm{O}_{2}$. 1D and 2D NMR data, in particular ${ }^{1} \mathrm{H},{ }^{1} \mathrm{H}$ COSY data, indicate a 4-isopropyl-1-methyl-cyclopentane partial structure. HMBC correlations from $15-\mathrm{H}_{3}$ to $\mathrm{C}-7 / \mathrm{C}-$ 8/C-9 and $7-\mathrm{H}$ to $\mathrm{C}-6 / \mathrm{C}-8 / \mathrm{C}-9 / \mathrm{C}-15$, defined the 3-methyl-2-furanone moiety. ${ }^{1} \mathrm{H},{ }^{13} \mathrm{C}$ HMBC 
correlations of $2-\mathrm{H}$ and $3-\mathrm{H}$ to $\mathrm{C}-5\left(\delta_{\mathrm{C}} 140.3\right)$, as well as $1-\mathrm{H}$ and $4-\mathrm{H}$ to $\mathrm{C}-6\left(\delta_{\mathrm{C}} 145.5\right)$, reveal the two moieties to be connected via a double bond. Key ROESY correlations of $7-\mathrm{H}$ to $4-\mathrm{H}$, 11-H, and 12-H, expose the double bond to be $E$ configured. Since overlapping signals seriously hampered assignment of ROESY data, analogy to compound $\mathbf{4}$ with very similar $\mathrm{H}, \mathrm{H}$ and $\mathrm{C}, \mathrm{H}$ coupling constants let to a common $1 R, 4 R$ configuration.

Rhodocorane I (4) differs from 3 by the presence of an additional hydroxy function at C-12 $\left(\delta_{\mathrm{C}} 66.3\right)$. Interproton distance correlations of $1-\mathrm{H}$ to $4-\mathrm{H}, 1-\mathrm{H}$ and $4-\mathrm{H}$ to $2-\mathrm{H}_{\mathrm{a}}$ and $3-\mathrm{H}_{\mathrm{a}}$ show these to be cofacial. A coupling constant $J_{\mathrm{H}, \mathrm{H}}=9.1 \mathrm{~Hz}$ between $4-\mathrm{H}$ and $11-\mathrm{H}$ confirms an antiperiplanar conformation between these protons. In addition to the strong ROESY correlations between $12-\mathrm{H}_{\mathrm{a} b \mathrm{~b}}$ and $3-\mathrm{H}_{\mathrm{b}}$ on the one side, and $13-\mathrm{H}_{3}$ and $7-\mathrm{H}$ on the other, this information defines the relative stereochemistry as $4 R^{*} 11 S^{*}$. Taken together with the common $1 R, 4 R$ configuration, the absolute configuration of rhodocorane I (4) is assigned $1 R, 4 R, 5 E, 11 S$.

The 1D and 2D NMR data of $\mathbf{5}$, namely rhodocorane J, was almost identical to $\mathbf{4}$, with the only major difference being in the ROESY correlations of $7-\mathrm{H}$ to $14-\mathrm{H}_{3}$ and $1-\mathrm{H}$, clearly indicating the double bond between $\mathrm{C}-5$ and $\mathrm{C}-6$ to be in the $Z$ configuration.

Rhodocorane $\mathrm{K}(6)$ has a molecular formula of $\mathrm{C}_{14} \mathrm{H}_{20} \mathrm{O}_{3}$ from HRESIMS data. ${ }^{1} \mathrm{H}$ and HSQC NMR spectra were similar to those of $\mathbf{4}$, but ${ }^{13} \mathrm{C}$ NMR data confirmed the presence of a conjugated ketone and a quaternary carbon instead of the $\mathrm{C}-5 / \mathrm{C}-6$ double bond. Based on HMBC correlations from both $1-\mathrm{H}$ and $4-\mathrm{H}$ to $\mathrm{C}-6$ and $\mathrm{C}-9$, the $\mathrm{C}-5$ spiro center was deduced, giving rise to an unusual spiro[4.4]nonene backbone. The relative configuration of $\mathbf{6}$ was determined from coupling constants and ROESY spectral data. These are analogous to $\mathbf{4}$ and $\mathbf{5}$, 
and with ROESY correlations between $7-\mathrm{H}$ and $13-\mathrm{H}_{3} / 14-\mathrm{H}_{3}$ indicate the absolute configuration of $1 R, 4 R, 5 S, 11 S$.

Rhodocorane L (7), was assigned the molecular formula $\mathrm{C}_{15} \mathrm{H}_{20} \mathrm{O}_{4}$, based on HRMS data. The ${ }^{1} \mathrm{H}$ and ${ }^{13} \mathrm{C}$ NMR data were similar to those of $\mathbf{1}$ and other rhodocoranes. The 4-isopropyl-1methyl-cyclopentane moiety was readily assigned from ${ }^{1} \mathrm{H},{ }^{1} \mathrm{H}$ COSY and ${ }^{1} \mathrm{H},{ }^{13} \mathrm{C} \mathrm{HMBC}$ correlations, while HMBC correlations from $9-\mathrm{H}$ to $\mathrm{C}-5 / \mathrm{C}-7 / \mathrm{C}-8 / \mathrm{C}-10$ and $15-\mathrm{H}_{3}$ to $\mathrm{C}-7 / \mathrm{C}-8$ / C-9 and C-6 (weaker ${ }^{4} J$ correlation) identified a highly oxidized six-membered ring structure typical for rhodocoranes B-E. The spirocenter C-5 was confirmed by HMBC correlations from both $1-\mathrm{H}$ and $4-\mathrm{H}$ to $\mathrm{C}-6$ and $\mathrm{C}-10$. An additional ring closure of $\mathrm{C}-12$ to $\mathrm{C}-9$ was required due to a COSY correlation between these protons. ROESY data (Figure 1) show H-2 $\beta, \mathrm{H}-3 \beta, \mathrm{H}-9$, and $\mathrm{H}-12$ to be interacting, and facing the opposite direction of $\mathrm{H}-1, \mathrm{H}-2 \alpha, \mathrm{H}-3 \alpha, \mathrm{H}-4$, and $\mathrm{H}-11$. An axial conformation of $11-\mathrm{H}$ and $12-\mathrm{H}$ is indicated by a large proton coupling constant $\left(J_{9,12}=\right.$ $10.8 \mathrm{~Hz}$ ). For the assignment of the $\mathrm{C}-5$ spiro center, a $J$-resolved HMBC experiment was conducted. The large coupling values ${ }^{3} J_{\mathrm{H} 1 \mathrm{C} 10}=8.3 \mathrm{~Hz}$ and ${ }^{3} J_{\mathrm{H} 4 \mathrm{C} 10}=7.6 \mathrm{~Hz}$, in contrast to the small values ${ }^{3} J_{\mathrm{H} 1 \mathrm{C} 6}=2.2 \mathrm{~Hz}$ and ${ }^{3} J_{\mathrm{H} 4 \mathrm{C} 6}=2.7 \mathrm{~Hz}$, indicated antiperiplanar conformations between these protons and $\mathrm{C}-10$, and synclinal conformations to $\mathrm{C}-6$, respectively. Thus, the absolute configuration can be assigned as $1 R, 4 R, 5 S, 9 R, 11 S, 12 R$.

The newly isolated metabolites showed weak activity against the yeasts Rhodotorula glutinis DSM 10134 and the plant pathogen Nematospora coryli DSM 6981 (see Table S1, supporting information). Rhodocoranes H (3) and I (4) also exhibit stronger activity against the filamentous fungi Mucor plumbeus MUCL49355 (MIC = 8.3 $\mu \mathrm{g} / \mathrm{mL})$, while 2 and 3 display antibacterial activity $\quad(\mathrm{MIC}=33.3-66.7 \mu \mathrm{g} / \mathrm{mL}) \quad$ against $\quad$ Bacillus $\quad$ subtilis $\quad$ DSM 10, Staphylococcus aureus DSM 346, Micrococcus luteus DSM 1790, and Escherichia coli mutant 
TolC. (Supporting information, Table S2). Rhodocorane G (2) showed cytotoxicity against cervix carcinoma cell lines $\mathrm{KB} 3.1\left(\mathrm{IC}_{50}=2.9 \mu \mathrm{M}\right)$, human adenocarcinoma cell line MCF-7 $\left(\mathrm{IC}_{50}=9.3 \mu \mathrm{M}\right)$, mouse fibroblast cell line $\mathrm{L} 929\left(\mathrm{IC}_{50}=5.6 \mu \mathrm{M}\right)$, and the human epidermoid carcinoma cell line A431 $\left(\mathrm{IC}_{50}=12.0 \mu \mathrm{M}\right)$.

To the best of our knowledge, metabolites 3-5 are the first reported cyclopentafuranylfuranones from nature. However such structures were used as intermediates in the total synthesis of acorenones. ${ }^{11}$ Rhodocoranes H-J (3-5) may play a role in the biosynthesis of spirononenes, and additional acorenones may be produced by Rhodotus palmatus. The biosynthesis of acoranes has been studied by Citron et al. 2011. ${ }^{12}$ Based on their findings, the formation of cyclopentafuranyl-pyranones can be explained through a cyclisation prior to the 1,2-hydride shift of (S)-bisabolyl cation to $(S)$-homobisabolyl cation occurs. Cyclopentafuranyl-furanones may be biosynthesized in a similar manner, requiring a decarboxylation in an earlier step. It remains to be determined whether one depends on the other, or whether the biosynthesis of these rhodocoranes even follows those of other acoranes.

Spiro[4.4]nonanes are relatively rare in nature, and only a few examples, such as the noracorane hemiketal bakerol and its congeners, ${ }^{13}$ have been reported. Rhodocorane L (7) exhibits a unique scaffold, with some similarity to the phospholipase $\mathrm{C}$ inhibitor hispidospermidin. ${ }^{14}$

\section{EXPERIMENTAL SECTION}


General Experimental Procedures. NMR spectra were obtained from a Bruker Avance III $500 \mathrm{MHz}$ spectrometer equipped with a BBFO(plus) SmartProbe $\left({ }^{1} \mathrm{H} 500 \mathrm{MHz},{ }^{13} \mathrm{C} 126 \mathrm{MHz}\right)$, and a Bruker Avance III $700 \mathrm{MHz}$ spectrometer equipped with a $5 \mathrm{~mm}$ TCI cryoprobe $\left({ }^{1} \mathrm{H} 700\right.$ $\left.\mathrm{MHz},{ }^{13} \mathrm{C} 175 \mathrm{MHz},{ }^{15} \mathrm{~N} 71 \mathrm{MHz}\right)$. Chemical shifts $\delta$ were referenced to methanol- $d_{4}\left({ }^{1} \mathrm{H}, \delta=\right.$ $\left.3.31 \mathrm{ppm} ;{ }^{13} \mathrm{C}, \delta=49.15 \mathrm{ppm}\right)$. HRESIMS mass spectra were measured on a Agilent 1200 series HPLC-UV system (Santa Clara, CA, USA) in combination with an ESI-TOF-MS (Maxis, Bruker) [column $2.1 \times 50 \mathrm{~mm}, 1.7 \mu \mathrm{m}, \mathrm{C}_{18}$ Acquity UPLC BEH (Waters), solvent A: MilliQ water $+0.1 \%$ formic acid; solvent B: acetonitrile $+0.1 \%$ formic acid, gradient: $5 \%$ B for $0.5 \mathrm{~min}$ increasing to $100 \% \mathrm{~B}$ in $19.5 \mathrm{~min}$, maintaining $100 \% \mathrm{~B}$ for $5 \mathrm{~min}$, $\mathrm{RF}=0.6 \mathrm{~mL} \mathrm{~min}{ }^{-1}$, UV detection 200-600 nm]. Optical rotation was recorded with a PerkinElmer 241 polarimeter. UV spectra were acquired using a Shimadzu UV-vis spectrophotometer UV-2450.

Fungal Material. Basidiomes of the wrinkled peach mushroom, Rhodotus palmatus, were collected in Mettlach, Germany, by H. Andersson at the annual meeting of the German Mycological Society on September 26, 2014. Corresponding cultures were obtained from its basidiospores and are stored at the mycological strain collection at the Microbial Drugs Department of the Helmholtz Centre for Infection Research (Braunschweig, Germany) under accession number STMA14334, as well as the Leibniz Institute DSMZ - German Collection of Microorganisms and Cell Cultures GmbH (Braunschweig, Germany). A dried specimen is deposited with the mycological herbarium of the State Museum of Natural History Karlsruhe, (Germany) under reference number KR-M-0008410. ${ }^{15}$ Its $5.8 \mathrm{~S}$ gene region, the internal transcribed spacer 1 and 2 (ITS), the large subunit (LSU), RNA polymerase II gene (RPB2), and translation elongation factor 1 alpha (TEF-1) were previously sequenced and published by 
Sandargo et al. ${ }^{8}$ and the sequence data are available from GenBank under accession numbers MK287617 (ITS), MK287618 (LSU), MK284231 (TEF-1), and MK292709 (RPB2).

Fermentation. Cultures of the strain Rhodotus palmatus STMA14334 were maintained on BAF agar (DSMZ medium 392). Fermentation was carried out as previously published, ${ }^{8}$ using $70 \mathrm{~L} \mathrm{ZM} 1 \frac{1}{2}$ medium in a $100 \mathrm{~L}$ bioreactor (B. Braun Melsungen AG, Germany / Type: 8015.1.01 / Nr.101, with a 3-step InterMIG-stirring system) at $24{ }^{\circ} \mathrm{C}$ and $150 \mathrm{rpm}$. The starting $\mathrm{pH}$ was set to 7.2 and $\mathrm{pO}_{2}$ level was maintained at $5 \%$. The fermentation process was stopped after depletion of free mannitol levels in the supernatant, after 15 days. The supernatant was centrifuged to remove any oatmeal and mycelial residues and extracted, following the procedures previously described for this strain, ${ }^{8}$ and filtered using the SPME Strata ${ }^{\mathrm{TM}}-\mathrm{X} 33$ u Polymeric RP cartridge (Phenomenex, Inc., Aschaffenburg, Germany), leading to $3.7 \mathrm{~g}$ extract.

Isolation of metabolites. The extract was pre-fractioned with a RP-MPLC [Kronlab ODSAQ $12016 \mathrm{C}_{18}, 48 \times 3 \mathrm{~cm}$ column (YMC Europe GmbH, Dinslaken, Germany), solvent A: water (Milli-Q), solvent B: acetonitrile; gradient: $10 \% \mathrm{~B}$ increasing to $100 \% \mathrm{~B}$ in $100 \mathrm{~min}$ and maintaining $100 \% \mathrm{~B}$ for $20 \mathrm{~min}$; flow rate $20 \mathrm{~mL} / \mathrm{min}$, UV detection at $210 \mathrm{~nm}$ ]. An MPLC fraction at 107-109 min yielded $0.5 \mathrm{mg}$ of $\mathbf{2}$, and another fraction at 113-115 min led to $10 \mathrm{mg}$ of compound 3. All other fractions were further purified via RP-HPLC utilizing the Synergi ${ }^{\mathrm{TM}}$ Polar RP $250 \times 50 \mathrm{~mm}, 80 \AA, 10 \mu \mathrm{m}$ (Phenomenex, Aschaffenburg, Germany); solvent A: MilliQ water $+0.1 \%$ formic acid, solvent B: acetonitrile $+0.1 \%$ formic acid, flow rate: $50 \mathrm{~mL} / \mathrm{min}$ at a Gilson PLC2250 Purification System (Limburg, Germany) using individually established gradients for each fraction. The MPLC fraction at $60-80 \mathrm{~min}$ of the crude extract was separated using a gradient of $10 \mathrm{~min}$ at $40 \%$ solvent $\mathrm{B}$, then increasing to $70 \%$ solvent $\mathrm{B}$ over a period of $30 \mathrm{~min}$, yielding in $2.9 \mathrm{mg}$ of 7 (21-21.5 min), and $4 \mathrm{mg}$ of compound 4 (23-24 min). Pre- 
fraction $80-88$ min was further fractioned with a gradient of 10 min at $40 \%$ solvent $\mathrm{B}$, then increasing to $60 \%$ solvent $\mathrm{B}$ within $30 \mathrm{~min} .14 \mathrm{mg}$ of a peak at $25.5-26 \mathrm{~min}$ were collected as metabolite 5. The adjacent MPLC pre-fraction of 88-97 min was separated within $45 \mathrm{~min}$ and a gradient from $50 \%$ to $100 \%$ solvent B. A peak at $21-22 \mathrm{~min}$ led to $4 \mathrm{mg}$ of $\mathbf{1}$. The MPLC fraction at 35-60 min of the crude product was purified using the VP Nucleodur $100-5 \mathrm{C}_{18}$ ec column, $250 \times 40 \mathrm{~mm}, 7 \mu \mathrm{m}$ (Macherey-Nagel, Düren, Germany) with a gradient of $10 \mathrm{~min}$ at $10 \%$ solvent $\mathrm{B}$, then increasing to $65 \%$ solvent $\mathrm{B}$ over a period of $45 \mathrm{~min}$. A peak at 33-34 min was isolated and yielded in $5 \mathrm{mg}$ compound $\mathbf{6}$.

Rhodocorane F (1), colorless oil; $[\alpha]^{25}-15(c 1, \mathrm{MeOH})$; UV (MeOH) $\lambda_{\max }(\log \varepsilon): 262$ (4.2) $\mathrm{nm} ;{ }^{1} \mathrm{H}$ and ${ }^{13} \mathrm{C}$ NMR data (see table 1), HRESIMS $[\mathrm{M}+\mathrm{Na}]^{+} \mathrm{m} / \mathrm{z} 287.1254,\left[\mathrm{M}-\mathrm{H}_{2} \mathrm{O}+\mathrm{H}\right]^{+}$ $m / z$ 247.1328, $[\mathrm{M}+\mathrm{H}]^{+} m / z 265.1433$ (calcd for $\mathrm{C}_{15} \mathrm{H}_{21} \mathrm{O}_{4}{ }^{+}, 265.1439$ ).

Rhodocorane $G$ (2), brown oil; $[\alpha]^{25}+40\left(c\right.$ 1, MeOH); UV (MeOH) $\lambda_{\max }(\log \varepsilon): 290$ (3.8), $205(\varepsilon=3.6) \mathrm{nm} ;{ }^{1} \mathrm{H}$ and ${ }^{13} \mathrm{C}$ NMR data (see table 1), HRESIMS $[\mathrm{M}+\mathrm{Na}]^{+} \mathrm{m} / z$ 271.1306, [M$\left.\mathrm{H}_{2} \mathrm{O}+\mathrm{H}\right]^{+} m / z$ 231.1376, $[\mathrm{M}+\mathrm{H}]^{+} m / z 249.1486$ (calcd for $\mathrm{C}_{15} \mathrm{H}_{21} \mathrm{O}_{3}{ }^{+}, 249.1490$ ).

Rhodocorane $H$ (3), brown oil; $[\alpha]_{\mathrm{D}}^{25}-250\left(c\right.$ 1, MeOH); UV (MeOH) $\lambda_{\max }(\log \varepsilon): 295$ (4.3), $201(3.7) \mathrm{nm} ;{ }^{1} \mathrm{H}$ and ${ }^{13} \mathrm{C}$ NMR data (see table 1), HRESIMS $[\mathrm{M}+\mathrm{Na}]^{+} \mathrm{m} / z$ 243.1352, [M$\left.\mathrm{H}_{2} \mathrm{O}+\mathrm{H}\right]^{+} m / z$ 203.1427, [M+H] $]^{+} m / z 221.1532$ (calcd for $\mathrm{C}_{14} \mathrm{H}_{21} \mathrm{O}_{2}{ }^{+}, 221.1541$ ).

Rhodocorane I (4), colorless oil; $[\alpha]^{25}{ }_{\mathrm{D}}-200$ (c 1, MeOH); UV (MeOH) $\lambda_{\max }(\log \varepsilon): 295$ (5.0), 200 (4.4) nm; ${ }^{1} \mathrm{H}$ and ${ }^{13} \mathrm{C}$ NMR data (see table 2), HRESIMS $[\mathrm{M}+\mathrm{Na}]^{+} \mathrm{m} / z$ 259.1308, [M$\left.\mathrm{H}_{2} \mathrm{O}+\mathrm{H}\right]^{+} m / z 219.1379[\mathrm{M}+\mathrm{H}]^{+} m / z 237.1485$ (calcd for $\mathrm{C}_{14} \mathrm{H}_{21} \mathrm{O}_{3}{ }^{+}, 237.1490$ ). 
Rhodocorane $J$ (5), brown oil; $[\alpha]^{25}{ }_{\mathrm{D}}+20\left(c\right.$ 1, MeOH); UV (MeOH) $\lambda_{\max }(\log \varepsilon): 296(3.9)$, 202 (3.2) nm; ${ }^{1} \mathrm{H}$ and ${ }^{13} \mathrm{C}$ NMR data (see table 2), HRESIMS $[\mathrm{M}+\mathrm{Na}]^{+} \mathrm{m} / z$ 259.1309, [M$\left.\mathrm{H}_{2} \mathrm{O}+\mathrm{H}\right]^{+} m / z 219.1380[\mathrm{M}+\mathrm{H}]^{+} m / z 237.1485$ (calcd for $\mathrm{C}_{14} \mathrm{H}_{21} \mathrm{O}_{3}{ }^{+}, 237.1490$ ).

Rhodocorane $K(6)$, brown oil; $[\alpha]^{25}+10(c 1, \mathrm{MeOH})$; UV (MeOH) $\lambda_{\max }(\log \varepsilon) 385(2.4)$, 275 (2.8), 220 (3.3), $201(3.3) \mathrm{nm} ;{ }^{1} \mathrm{H}$ and ${ }^{13} \mathrm{C}$ NMR data (see table 2), HRESIMS [M+Na] ${ }^{+} \mathrm{m} / \mathrm{z}$ 259.1305, $\left[\mathrm{M}-\mathrm{H}_{2} \mathrm{O}+\mathrm{H}\right]^{+} \mathrm{m} / z$ 219.1382, $[\mathrm{M}+\mathrm{H}]^{+} \mathrm{m} / z 237.1483$ (calcd for $\mathrm{C}_{14} \mathrm{H}_{21} \mathrm{O}_{3}{ }^{+}, 237.1490$ ).

Rhodocorane L (7), brown oil; $[\alpha]_{\mathrm{D}}^{25}+20(c 1, \mathrm{MeOH})$; UV (MeOH) $\lambda_{\max }(\log \varepsilon): 285$ (3.8), 201 (3.6) $\mathrm{nm} ;{ }^{1} \mathrm{H}$ and ${ }^{13} \mathrm{C}$ NMR data (see table 2), HRESIMS $[\mathrm{M}+\mathrm{Na}]^{+} \mathrm{m} / z$ 287.1256, [M$\left.\mathrm{H}_{2} \mathrm{O}+\mathrm{H}\right]^{+} m / z$ 247.1329, [M+H] $]^{+} m / z 265.1436$ (calcd for $\mathrm{C}_{15} \mathrm{H}_{21} \mathrm{O}_{4}{ }^{+}, 265.1440$ ).

Antimicrobial Activity. The minimum inhibitory concentration (MIC) was evaluated following a previously published protocol in a serial dilution assay in 96-well microtiter plates, using YM media (10 g/L malt extract, $4 \mathrm{~g} / \mathrm{L}$ glucose, $4 \mathrm{~g} / \mathrm{L}$ yeast extract, $\mathrm{pH}$ 6.3) for yeasts and filamentous fungi and BD Difco ${ }^{\mathrm{TM}}$ Mueller Hinton Broth for bacteria. ${ }^{16}$

Cytotoxicity Assay. Cytotoxicity levels in vitro were determined with the MTT (3-(4,5dimethylthiayol-2-yl)- 2,5-diphenyltetrayolium bromide) assay in 96-well-plates, as previously described ${ }^{14}$ against the mouse fibroblast cell line L929, the cervix carcinoma cell line KB3.1, the human adenocarcinoma cells MCF-7, and the human epidermoid carcinoma cell line A431. 


\section{ASSOCIATED CONTENT}

Supporting Information. The following files are available free of charge.

HRESIMS and NMR spectroscopic data of 1-7, detailed biological activities of 1-7. (PDF)

AUTHOR INFORMATION

Corresponding Author

*Tel: +49 5316181 4256. E-mail: frank.surup@helmholtz-hzi.de

\section{ORCID}

Marc Stadler: 0000-0002-7284-8671

Frank Surup: 0000-0001-5234-8525

Present Addresses

$\ddagger$ Friedrich-Schiller-University Jena, 07743 Jena, Germany.

\section{Author Contributions}

The manuscript was written through contributions of all authors. All authors have given approval to the final version of the manuscript.

\section{Funding Sources}

BS and FS are grateful for support by the German Research Foundation, grant SU936/1-1.

\section{Notes}

The authors declare no competing financial interest. 


\section{ACKNOWLEDGMENTS}

We are highly grateful to J. Schnieber (DGfM) for the beautiful pictures of $R$. palmatus fruiting bodies. We thank L. Kaysan for assisting MM with recording optical rotations and UV spectra, W. Collisi, C. Kakoschke, C. Bergmann, S. Bernecker, R. Sterlinski, and A. Perreth for excellent technical support, and R. Jansen for proofreading of the manuscript.

\section{ABBREVIATIONS}

NMR nuclear magnetic resonance, HRESIMS high-resolution electron spray ionization mass spectrometry.

\section{REFERENCES}

(1) Sandargo, B.; Chepkirui, C.; Cheng, T.; Chaverra-Muñoz, L.; Thongbai, B.; Stadler, M.; Hüttel Biotechnology Advances. 2019, 37, 107344.

(2) a) Novak, R. Ann. N. Y. Acad. Sci. 2011, 1241, 71-81; b) FDA approval of lefamulin on 08/19/2019.

(3) a) Sandargo, B.; Thongbai, B.; Stadler, M.; Surup, F. J. Nat. Prod. 2018, 81, 286-291; b) Sandargo, B.; Thongbai, B.; Praditya, D.; Steinmann, E.; Stadler, M.; Surup, F. Molecules 2018, 23, 2697.

(4) Karwehl, S.; Stadler, M. Curr. Top. Microbiol. Immunol. 2016, 398, 303-338.

(5) Redhead, S. A. Can. J. Bot. 1989, 67, 3003-3062.

(6) European Council for the Conservation of Fungi. Country Reports for the Period 2000$2005 ; 2005$.

(7) Sundberg, W. J.; Methven, A. S.; Monoson, H. L. Mycotaxon 1997, 65, 403-410.

(8) Sandargo, B.; Michehl, M.; Praditya, D.; Steinmann, E.; Stadler, M.; Surup, F. Org. Lett. 2019, 21, 3286-3289. 
(9) Brock, N. L.; Dickschat, J. S. Eur. J. Org. Chem. 2011, 5167-5175.

(10) Pesaro, M.; Bachmann, J.-P. J.C.S. Chem. Comm. 1978, 203-204.

(11) White, J. D.; Ruppert, J. F.; Avery, M. A.; Torii, S.; Nokamilc, J. J. Am. Chem. Soc. 1981, 103, 1813-1821.

(12) Citron, C. A.; Riclea, R.; Brock, N. L.; Dickschat, J. S. RSC Adv. 2011, 1, 290-297.

(13) Cool, L. G.; Kim, Y.; Zavarin, E.; Ball, G. E. Phytochemistry 1994, 36, 1283-1285.

(14) Ohtsuka, T.; Itezono, Y.; Nakayama, N.; Sakai, A.; Shimma, N.; Yokose, K.; Seto, H. J. Antibiot. 1994, 47, 6-15.

(15) Scholler, M. Staatl. Museum Fuer Naturkunde Karlsruhe (SMNK), Fungal Herbarium. 2019.

(16) Surup, F.; Thongbai, B.; Kuhnert, E.; Sudarman, E.; Hyde, K.D.; Stadler M. J. Nat. Prod. 2015, 78, 934-938. 


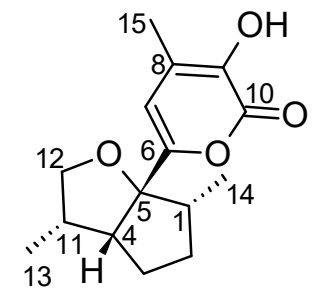

1<smiles>Cc1cc(C2=C(C(C)C)CC[C@H]2C)oc(=O)c1O</smiles>

2

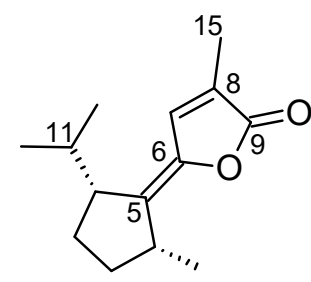

3

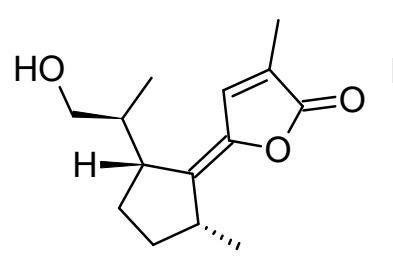

4<smiles>CC1=C/C(=C2\[C@H](C(C)CO)CC[C@H]2C)OC1=O</smiles>

5

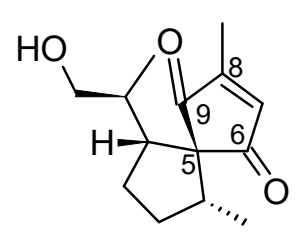

6

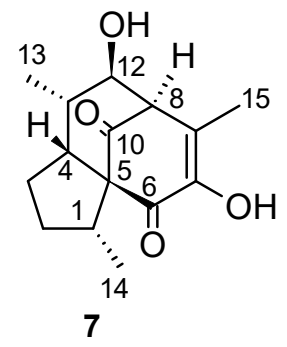

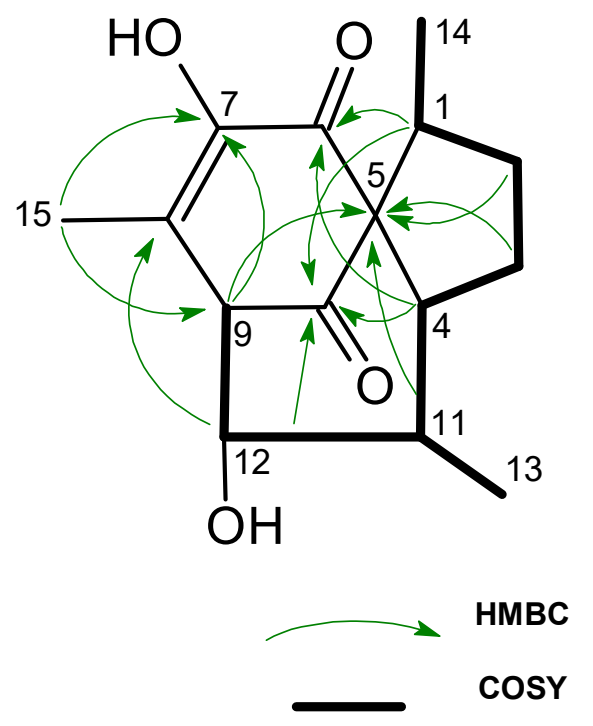

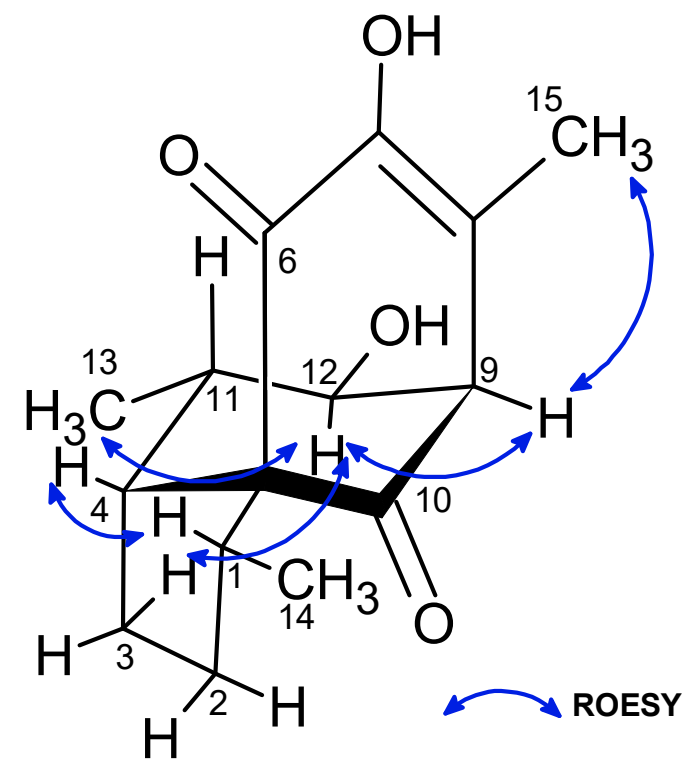

Figure 1. Key HMBC, COSY and ROESY correlations of rhodocorane L (7). 
Table 1: NMR data of rhodocoranes F-H (1-3) in methanol- $d_{4}$.

\begin{tabular}{|c|c|c|c|c|c|c|}
\hline \multirow[b]{2}{*}{ Pos. } & \multicolumn{2}{|r|}{$1^{\mathrm{a}}$} & \multicolumn{2}{|r|}{$2^{\mathrm{a}}$} & \multicolumn{2}{|r|}{$3^{\mathrm{b}}$} \\
\hline & $\delta_{\mathrm{C}}$, type & $\delta_{\mathrm{H}}(J$ in $\mathrm{Hz})$ & $\delta_{\mathrm{C}}$, type & $\delta_{\mathrm{H}}(J$ in $\mathrm{Hz})$ & $\delta_{\mathrm{C}}$, type & $\delta_{\mathrm{H}}(J$ in $\mathrm{Hz})$ \\
\hline 1 & $45.6, \mathrm{CH}$ & $2.44, \mathrm{~m}$ & $42.7, \mathrm{CH}$ & $3.11, \mathrm{~m}$ & $38.2, \mathrm{CH}$ & 3.06, tq $(7.5,7.1)$ \\
\hline $2 \mathrm{a}$ & $34.9, \mathrm{CH}_{2}$ & $1.35, \mathrm{~m}$ & $32.3, \mathrm{CH}_{2}$ & $1.51, \mathrm{~m}$ & $33.2, \mathrm{CH}_{2}$ & $1.50, \mathrm{~m}$ \\
\hline $\mathrm{b}$ & & $1.87, \mathrm{~m}$ & & $2.07, \mathrm{~m}$ & & $1.99, \mathrm{~m}$ \\
\hline $3 \mathrm{a}$ & $23.8, \mathrm{CH}_{2}$ & $1.76, \mathrm{~m}$ & $31.2, \mathrm{CH}_{2}$ & 2.42, ddd $(17.2,8.8,4.2)$ & $29.1, \mathrm{CH}_{2}$ & $1.67, \mathrm{~m}$ \\
\hline $\mathrm{b}$ & & & & 2.55, ddd $(17.2,9.0,7.6)$ & & $1.93, \mathrm{~m}$ \\
\hline 4 & $54.6, \mathrm{CH}$ & $2.75, \mathrm{~m}$ & $150.9, \mathrm{C}$ & & $50.9, \mathrm{CH}$ & \\
\hline 5 & $95.4, \mathrm{C}$ & & $130.2, \mathrm{C}$ & & $140.3, \mathrm{C}$ & \\
\hline 6 & $162.4, \mathrm{C}$ & & 155.3, C & & $145.5, \mathrm{C}$ & \\
\hline 7 & $113.1, \mathrm{C}$ & $6.28, \mathrm{~s}$ & $113.7, \mathrm{CH}$ & $6.22, \mathrm{~s}$ & $138.2, \mathrm{CH}$ & $7.46, \mathrm{q}(1.4)$ \\
\hline 8 & 133.3, $\mathrm{CH}$ & & $132.3, \mathrm{C}$ & & $128.4, \mathrm{C}$ & \\
\hline 9 & 141.0, C & & 141.3, C & & 173.3, C & \\
\hline 10 & 163.1, C & & $164.4, \mathrm{C}$ & & - & \\
\hline 11 & $37.7, \mathrm{CH}$ & $2.49, \mathrm{~m}$ & $29.1, \mathrm{CH}$ & $3.36, \mathrm{~m}$ & $32.1, \mathrm{CH}$ & 1.82, dseptd $(6.9,6.7,2.0)$ \\
\hline 12 & $76.7, \mathrm{CH}_{2}$ & $\begin{array}{l}3.37, \mathrm{dd}(10.8,7.8) \\
4.02, \mathrm{t}(7.8)\end{array}$ & $21.58, \mathrm{CH}_{3}$ & $1.04, d(6.9)$ & $22.4, \mathrm{CH}_{3}$ & $0.94, d(6.7)$ \\
\hline 13 & $12.1, \mathrm{CH}_{3}$ & $1.00, \mathrm{~d}(6.9)$ & $21.60, \mathrm{CH}_{3}$ & $1.09, \mathrm{~d}(6.9)$ & $20.3, \mathrm{CH}_{3}$ & $0.97, \mathrm{~d}(6.7)$ \\
\hline 14 & $13.2, \mathrm{CH}_{3}$ & $0.92, \mathrm{~d}(6.7)$ & $20.5, \mathrm{CH}_{3}$ & $1.07, \mathrm{~d}(6.8)$ & $20.9, \mathrm{CH}_{3}$ & $1.22, \mathrm{~d}(7.1)$ \\
\hline 15 & $12.0, \mathrm{CH}_{3}$ & $2.30, \mathrm{~s}$ & $12.0, \mathrm{CH}_{3}$ & $2.33, \mathrm{~s}$ & $10.6, \mathrm{CH}_{3}$ & 1.96, br s \\
\hline
\end{tabular}

${ }^{\mathrm{a} 1} \mathrm{H} 500 \mathrm{MHz},{ }^{13} \mathrm{C} 125 \mathrm{MHz},{ }^{\mathrm{b}} \mathrm{H} 700 \mathrm{MHz},{ }^{13} \mathrm{C} 175 \mathrm{MHz}$. 
Table 2: NMR data of rhodocoranes I-L in methanol- $d_{4}$.

\begin{tabular}{|c|c|c|c|c|c|c|c|c|}
\hline \multirow{2}{*}{ Pos } & \multicolumn{2}{|r|}{$4^{a}$} & \multicolumn{2}{|c|}{$5^{\mathrm{a}}$} & \multicolumn{2}{|c|}{$6^{\mathrm{a}}$} & \multicolumn{2}{|r|}{$7^{\mathrm{b}}$} \\
\hline & $\delta_{\mathrm{C}}$, type & $\delta_{\mathrm{H}}(\mathrm{J}$ in $\mathrm{Hz})$ & $\delta_{\mathrm{C}}$, type & $\delta_{\mathrm{H}}(\mathrm{J}$ in $\mathrm{Hz})$ & $\delta_{\mathrm{C}}$, type & $\delta_{\mathrm{C}}$, type & $\delta_{\mathrm{C}}$, type & $\delta_{\mathrm{H}}(\mathrm{J}$ in $\mathrm{Hz})$ \\
\hline 1 & $38.1, \mathrm{CH}$ & $3.06, \operatorname{tq}(8.0,6.9)$ & $37.7, \mathrm{CH}$ & $3.04, \mathrm{~m}$ & $46.2, \mathrm{CH}$ & $2.29, \mathrm{~m}$ & $38.7, \mathrm{CH}$ & $2.63, \mathrm{~m}$ \\
\hline $2 \mathrm{a}$ & $33.2, \mathrm{CH}_{2}$ & $1.50, \mathrm{~m}$ & $33.6, \mathrm{CH}_{2}$ & $1.55, \mathrm{~m}$ & $32.6, \mathrm{CH}_{2}$ & $1.64, \mathrm{~m}$ & $28.9, \mathrm{CH}_{2}$ & $1.54, \operatorname{td}(12.5,3.8)$ \\
\hline $2 b$ & & $2.01, \mathrm{~m}$ & & $1.89, \mathrm{~m}$ & & $1.96, \mathrm{~m}$ & & $1.89, \mathrm{~m}$ \\
\hline $3 a$ & $30.6, \mathrm{CH}_{2}$ & $1.68, \mathrm{~m}$ & $28.8, \mathrm{CH}_{2}$ & $1.79, \mathrm{~m}$ & $30.0, \mathrm{CH}_{2}$ & $2.08, \mathrm{~m}$ & 24.2, $\mathrm{CH}_{2}$ & $1.78, \mathrm{~m}$ \\
\hline $3 b$ & & $1.96, \mathrm{~m}$ & & & & $\begin{array}{l}1.82, \operatorname{tdd}(12.3, \\
10.2,4.2)\end{array}$ & & $1.31, \mathrm{~m}$ \\
\hline 4 & $46.1, \mathrm{CH}$ & 2.76, ddd $(9.1,7.0,2.1)$ & $47.7, \mathrm{CH}$ & $2.96, \mathrm{q}(7.1)$ & $51.0, \mathrm{CH}$ & $2.31, \mathrm{~m}$ & $54.8, \mathrm{CH}$ & 2.15, ddd $(13.0,8.1,6.0)$ \\
\hline 5 & $139.4, \mathrm{C}$ & & $139.4, \mathrm{C}$ & & $64.8, \mathrm{C}$ & & 74.0, C & \\
\hline 6 & 145.6, C & & 145.0, C & & 209.7, C & & $194.4, \mathrm{C}$ & \\
\hline 7 & $138.3, \mathrm{CH}$ & $7.46, \mathrm{q}(1.4)$ & 137.6, $\mathrm{CH}$ & $7.51, \mathrm{q}(1.4)$ & 163.6, C & & $148.4, \mathrm{C}$ & \\
\hline 8 & $128.5, \mathrm{C}$ & & $128.5, \mathrm{C}$ & & $146.6, \mathrm{CH}$ & $7.04, q(1.5)$ & $128.8, \mathrm{C}$ & \\
\hline 9 & 173.3, C & & 173.2, C & & 207.5, C & & $64.1, \mathrm{CH}$ & $3.28, \mathrm{~d}(4.4)$ \\
\hline 10 & / & & I & & / & & 206.7, C & \\
\hline 11 & $39.6, \mathrm{CH}$ & $1.72, \mathrm{~m}$ & $39.2, \mathrm{CH}$ & $2.15, \mathrm{~m}$ & $39.7, \mathrm{CH}$ & $\begin{array}{l}1.48, \mathrm{dtd}(10.5 \\
6.8,3.4)\end{array}$ & $34.3, \mathrm{CH}$ & $1.90, \mathrm{~m}$ \\
\hline 12 & $66.3, \mathrm{CH}_{2}$ & $\begin{array}{l}3.62, \mathrm{dd}(10.7,4.0) \\
3.48, \mathrm{dd}(10.7,6.6)\end{array}$ & 66.4, $\mathrm{CH}_{2}$ & $\begin{array}{l}1.02, \mathrm{~d}(7.1) \\
3.61, \mathrm{dd} \\
(10.7,4.0)\end{array}$ & 67.0, $\mathrm{CH}_{2}$ & $\begin{array}{l}3.49, \mathrm{dd}(10.8, \\
3.2) \\
3.25, \mathrm{dd}(10.8, \\
6.6)\end{array}$ & 74.7, $\mathrm{CH}$ & $3.71, \mathrm{dd}(10.8,4.5)$ \\
\hline 13 & $17.3, \mathrm{CH}_{3}$ & $0.95, \mathrm{~d}(6.9)$ & $16.8, \mathrm{CH}_{3}$ & $\begin{array}{l}3.39, \mathrm{dd} \\
(10.7,8.1)\end{array}$ & $17.5, \mathrm{CH}_{3}$ & $0.63, d(6.7)$ & 14.7, $\mathrm{CH}_{3}$ & $1.01, \mathrm{~d}(6.9)$ \\
\hline 14 & $21.1, \mathrm{CH}_{3}$ & $1.25, \mathrm{~d}(7.1)$ & $22.9, \mathrm{CH}_{3}$ & $1.19, \mathrm{~d}(7.1)$ & $15.0, \mathrm{CH}_{3}$ & $0.71, \mathrm{~d}(6.9)$ & 14.6, $\mathrm{CH}_{3}$ & $1.09, \mathrm{~d}(6.9)$ \\
\hline 15 & $10.6, \mathrm{CH}_{3}$ & $1.96, \mathrm{~s}$ & $10.6, \mathrm{CH}_{3}$ & $1.96, \mathrm{~s}$ & $11.4, \mathrm{CH}_{3}$ & $2.10, \mathrm{~d}(1.5)$ & $18.6, \mathrm{CH}_{3}$ & $2.06, \mathrm{~s}$ \\
\hline
\end{tabular}

${ }^{\mathrm{a}}{ }^{1} \mathrm{H} 500 \mathrm{MHz},{ }^{13} \mathrm{C} 125 \mathrm{MHz},{ }^{\mathrm{b}} \mathrm{H} 700 \mathrm{MHz},{ }^{13} \mathrm{C} 175 \mathrm{MHz}$. 